\title{
Analysis of the Perceptions of School Administrators on the Recent Published Regulation
}

\author{
Saduman Kapusuzoglu, Habibe Ozturk \\ Hacettepe University, Faculty of Education, Ankara, Turkey \\ saduman.kapusuzoglu@hacettepe.edu.tr
}

\begin{abstract}
The aim of study is to examine the perceptions of school administrators about the regulation published on 10th June 2014. This study is a qualitative research and in order to acquire the data phenomenological method, which provides to focus on cases that we are aware of but do not have deep and detailed insight, was used. The target group of the study included 5 primary, 5 secondary and 2 high school administrators in Ankara province Polatl district. The target group was designed based on purposive sampling method. The data was collected by using semi-structured interview method. Content analysis method was conducted to analyze the data. School principals in the study, expressed their ideas as follows; the assessments for school managements should be done by a lawful and objective exam. The exam should be written. The exam should be esteemed at; general ability, education management and regulations. The written exam should apply for both work of director and assistant director. Although the first rule for being appointed to educational institutions is being selected by an exam, the management knowledge and ability, master's degree, in service training on management etc. should be given importance, too.
\end{abstract}

Keywords: Regulations related to educational administration, principal selection, principal assignment

\section{Introduction}

Principals are the main characters in the formation of efficient and qualified schools. Besides their bureaucratic status, principals are regarded as the most important and effective individuals of schools who regulate the learning climate, influence a sense of belonging for teachers and the success of students, initiate decision making, facilitating and change (Balyer and Gündüz, 2011; Korkmaz, 2005). School principals need to be the leaders of the schools besides being the administrators of the schools they manage. Therefore, the selection and training of school principals comes to the fore as an important factor which influences the educational system and the success of students (Süngü, 2012). The regulations to which educational administration appointment criteria are related frequently change. From 2004 until today, 8 regulations have changed (the 2004, 2006, 2007, 2008, 2009, 2011, 2013, 2014 administrator appointment regulations). The Administrator Appointment and Translocation Regulations prior to 2014 have been subject to various criticisms in terms of content and scoring metrics in the studies carried out by Bakioğlu and Özcan (2001), Cemaloğlu (2005), Günay (2004), Korkmaz (2005), Serin (2007), Silah (2001), Özmen and Kömürlü (2010), Taş and Önder (2010), Turan and Şişman (2000), Yeloğlu (2008), Demir and Pınar (2013). As a result of all these criticisms and discussions, the previous circulars and regulations have been revised by the Ministry of National Education and a new Regulation on the Appointment of Educational Institution Administrators affiliated with the Ministry of National Education has been published (Doğan, Demir and Pınar, 2014).

Researching whether the new regulation on the appointment of administrators which became effective as of 2014 has brought the required solutions to the observed discussion, deficiency and problems related to the regulations published previously, determining its influence, positive and negative reflections on the related people and its content and scoring criteria are the main aims of this study. It is regarded that analyzing the current state of the appointment of administrators based on the views of administrators and presenting suggestions is important. In this respect, the problem statement of the study is as follows: The Analysis of the Perceptions of Administrators in relation to the Regulation published on 10.06.2014 on the Appointment of Administrators of Educational Institutions Affiliated with the Ministry of National Education (MEB, 2014).

Purpose of the Study: In the study, it has been aimed at analyzing the perceptions of primary, middle and high-school administrators on the related regulation: 
- What are the views of principals on the new regulation?

- Do the views differ in accordance with the demographic characteristics of the principals?

\section{Methodology}

The study is a qualitative study in which the views of the administrators have been obtained through semistructured open-ended questions. The study sample which has been selected through the purposeful sampling method consists of 5 primary, 5 middle school and 2 high-school principals who are employed in official schools located in Polatlı district of Ankara city.

Study Design: This study has been designed as a phenomenological study with the qualitative approach. Taking the answers the school administrators have given to the interview questions as the starting point, the phenomenological design has been preferred in order to display the principals' views on the regulation in relation to their appointment in detail and to analyze in-depth the perception of the principals on the regulation based on the views they have stated.

Data Collection Tool: In the study, the Semi-Structured Interview form consisting of open-ended questions has been used in order to determine the views of administrators employed in institutions affiliated with the Ministry of National Education on the Regulation on the Assignment of Administrators published on 10.06.2014 in the Official Gazette in terms of its content, the scoring criteria and the appointment process of administrators. Prior to the preparation of the interview questions, the regulation has been analyzed in-depth and the sub-headings determined within the framework of the regulation and the studies in the body of literature have been compared in detail. The draft interview form questions prepared as a result of the comparison have been evaluated in line with the purpose of the study by an academic member who is an expert in his field. Data related to the study have been collected through interviews conducted in the schools of the participants within the scope of the study. The participants involved in the study have been informed about the privacy process of personal information, given explanations that personal information is to be kept private and guaranteed that obtained data will not be used outside of the purpose of the study.

Analysis of Data: In the qualitative study design, it is important to display the views and points of view of the administrators on the study subject which have been expressed both openly and indirectly without prejudice and the line-by-line analysis approach has been used to make this possible. As data analysis unit or body, word groups and sentences have been selected (Patton, 2002; Charmaz, 2006). When the words and concepts used by the participants of the study inadequate in the process of coding, other concepts which can best express the views of the participants have been used by the researchers as codes. In the interpretation of interview data, inductive descriptive analysis, content analysis and constant comparison technique has been used (Coffey and Atkinson, 1996; Marshall and Rossman, 1999; Miles and Huberman 1994). Data obtained from the participants through content analysis have been analyzed and the codes which evoke the same concepts have been united under the common categories. In the last stage, cohesion has been achieved from the themes emerging from data and these have been interpreted. In order to determine whether it has embodied the whole data under each theme which have emerged during the thematic coding process, the views of the field experts have been consulted frequently and the shortages and errors in the thematic coding process have been corrected in line with the feedback. In this study, the constant comparison data analysis method has been used along with content analysis. During the analysis process of the study data, the constantly repeated facts and events within the scope of the answers given by the participants have been determined, compared and it has been attempted to reach categories and themes through the induction method. According to Mills (2003), it is more appropriate to use the concepts of plausibility, transmissibility, consistency and approvability, rather than the concepts of validity and reliability in these cases in the study.

\section{Findings and Interpretation}

The school principals have been asked 23 questions on the regulation and the answers given to these questions have been analyzed one by one. With the results reached through the general evaluation, suggestions have been given place to. The findings obtained as a result of the questions directed to the 
educational administrators and the analysis of the answers given to these questions has been presented below.

What are your views on the modification of the Regulation on the Appointment and Dislocation of Administrators of Educational Institutions affiliated with the MNE as the Regulation on the Assignment of Educational Institutions affiliated with MNE and their Administrators?

Except for Participant-1, Participant -4, Participant -7, Participant -9 and Participant -10, all participants have stated negative views on the appointment of administrators. Participant-2 has expressed his views as follows: "In fact, you can understand the different between the two from the title of the regulation. While one is a regulation on appointment, the other is a regulation on assignment. Unfortunately, today's assignments are political. The quality has been reduced to minimum and there is no respect for the authority. Democracy has been destroyed."

What are your views about the modification made in the article "Having available lessons in order to able to be appointed to the educational institution to be applied to in the related fields or in return for a monthly salary" in the regulation published on 4 August, 2013 as "Having the qualification of being able to be appointed to the educational institution to be assigned to as a teacher in the related field as of the date of the assignment" in the regulation published on 10 June, 2014?

In terms of having the qualification of being able to be appointed to the educational institution to be assigned to as a teacher in the related field, all participants have expressed positive views except for Participant-5, Participant-6 and Participant-9. Participant-1 has expressed the following: "The administrator to be assigned should not be unfamiliar with his institution" and has argued in the favor of the related article.

What are your views on the modification made in the article "Not having been relieved of administrative duty or not having received forfeiture of allowance or not having been given a heavier disciplinary penalty in the last four years due to legal or administrative investigation" for people to be appointed as administrators in the regulation published on 4 August, 2013, as "Not having been relieved of administrative duty in the last four years due to legal or administrative investigation" in the regulation published on 10 June, 2014?

Except for Participant-2 and Participant-3, all participants have expressed that this article is fir and proper and that this should be the case in practice as well. Participant- 2 has stated that this article should not be limited with only the last 4 years and should include the whole employment period as follows: "In my opinion, if the last four years condition is removed and the person has received a severe penalty during his whole employment period, then he should be prevented from being assigned as an administrator." Participant-3 has underlined his views as follows: "A person who has been relieved of administrative duty due to legal or administrative investigation not only in the last four years should never be appointed as an administrator."

The following qualifications are sought for in people to be assigned as administrators:

a) Being a higher-education graduate,

b) Working as a teacher in the Ministry's personnel as of the final application date,

c) Having the qualification of being able to be appointed as a teacher in the related field as of the assignment date to the educational institution to be assigned to,

d) Not having been relieved of administrative duty in the last for years due to legal or administrative investigation as of the assignment date.

If there are other qualifications you would like to add to this article, please state these.

While Participant-5 has stated the following in terms of the general qualifications to be sought for in those to be assigned as administrators "Since the action here is assignment of duty and it is for a temporary period of time, there is no need to increase the qualifications and make them more difficult", the other participants have suggested the addition of the following qualifications:

a. Determining whether the person has administrative skills by adding a period of internship (Participant-1, Participant-4)

b. Having a post-graduate degree in the area of administration (Participant-2, Participant -7, Participant 10, Participant -11) 
c. Giving priority to people with doctorate degrees in Educational Sciences and administrative fields (Participant -2, Participant -7)

d. These general terms should be the preconditions for the written examination and receiving a score of 70 and above in the written examination should be the only condition (Participant-3)

e. $\quad$ Having been participated in at least 1 project (Participant -11, Participant -8)

f. Having worked as a teacher for 10 years

g. Administrators should be assigned from those who are not teachers. They should be selected for assignment among principals, graduates of Public Administration, Political Sciences, Economics or Business Administration and vice principals should be selected from civil servants who are high-school or university graduates (Participant-9).

"People to be assigned as principals should have at least one of the following qualifications:

a. Having worked as a principle,

b. Having worked as a head vice principal for at least two years,

c. Having worked as a founding principal, vice principal and teacher with the authority of a principal separately or including having worked as head vice principal for a total of at least three years,

d. Having worked as a unit head or higher positions other than the Ministry's education and teaching services class,

e. Having worked as a teacher in the Ministry's personnel for at least eight years acting as principal."

Do you think that the terms stated in this article of the regulation are sufficient?

Which one or ones in your opinion are the most necessary?

Are there other special conditions you would like to add to these qualifications?

While a majority of the participants viewed these conditions as sufficient in terms of the special qualifications sought for in people to be assigned as principals, Participant-2 has stated that the $d$ paragraph of the related article should be removed as follows: "The administrative position is earned through education and experience. Principals should be selected from people who have previously worked as vice principals and completed their post-graduate education in the area of administrative field."

People to be assigned as head vice principals or vice principals should carry at least one of the following qualifications:

a. Having worked as a principle, founding principle, head vice principle, vice principle or teacher with the authority of a principal

b. Having worked as a unit head or higher positions other than the Ministry's education and teaching services class

c. Having worked as a teacher in the Ministry's personnel for at least four years acting as principal."

Do you think that the terms stated in this article of the regulation are sufficient?

Which one or ones in your opinion are the most necessary?

Are there other special conditions you would like to add to these qualifications?

While Participant-1, Participant-5, Participant-6, Participant-7, Participant-10 have found this article of the regulation sufficient, Participant-3, Participant-4, Participant-8, Participant-9 and participant-11 have underlined that the article has shortcomings. Almost all of the participants have regarded the $c$ paragraph of the article as the most necessary qualification. Participant- 4 has stated that an internship period should be added to the article, Participant-8 has stated that a written examination conditions should immediately be brought and Participant-11 has stated that a post-graduate degree conditions should be added for the vice principal position as well.

What are your views on the article "The administrators are assigned for 4 years"? In terms of administrators continuing their duties through assignment and not appointment, the administrators have stated different views. Participant-2, Participant-3, Participant-5, Participant-6, Participant-7, Participant-8, Participant- 9 and Participant-10 have expressed that assignment is not a proper method. While Participant- 6 
has stated "I do not find assignment appropriate at all. I believe that it will cause personnel to be totally politicized administrators to be tied to the higher position with a feeling of gratitude and not be able to carry out their duties in a fair manner", Participant-1 has stated that he has found this method appropriate and expressed "The position not being permanent increases the loyalty of the administrators both towards the teachers and this occupation. This facilitates terminating the duties of unsuccessful administrators and evaluating their performance."

What are your views about the article "At least one of the religious middle school vice principals is selected from teachers who have taken Religious Culture and Moral Knowledge or vocational lessons; at least one of the religious high-school and vocational and technical education institution vice principals is selected from teachers who have taken vocational lessons; at least one of the social sciences high-school vice principals is selected from teachers who have taken Turkish Language and Literature, History, Geography, philosophy or Psychology lessons; at least one of the fine arts vice principals is selected from teachers who have taken Visual Arts, Painting or Music lessons; at least one of the sports high-school vice principals is selected from teachers who have taken Physical Education lessons; and at least one of the special education institution vice principals is selected from teachers who have taken guidance or special education lessons"?

While 9 participants have stated that they found this article appropriate, 2 participants (Participant- 6 and Participant-8) have stated that since administration and teachers' branches are not related, they are against such a positive discrimination. Participant-7 has expressed his views as follows: "I think that it is an accurate decision. At least one of the administrators being experienced in a branch related to the school type is a perfectly appropriate practice in terms of the nature of this work."

What are your views on the assignment of at least one vice principal from female candidates in all girls schools or educational institutions which have boarding female students or in coeducation schools which have three or more vice principals? While only Participant- 8 has stated a negative view on this article, all of the other participants share the same view that this article is fit and proper. Participant-8 has expressed his views as follows: "I do not accept such a discrimination to be made; there should not be discrimination in terms of gender." Participant-1 who has found the article appropriate has stated "This article will cause the ratio of women and administration and facilitate communication; Participant-11 has stated "This is a quite accurate article, because I believe that female administrators will understand the needs of female students better; Participant-5 has stated "The priority should be given to women, but the article should be modified to state that in cases where there are no female candidates, male candidates should be assigned" and offered their suggestions.

What are your views on the article "The duties of people who are assigned as administrators to the same educational institution and have worked under the same title for more than four years and less than eight years at their educational institutions are terminated as indicated in this regulation as of the completion date of eight years"?

In terms of working under the same title at the same school for a maximum of eight years, all participants with the exception of Participant-2 and Participant- 8 have stated positive views. Participant- 2 has stated in terms of successful candidates working at the same institution that a year condition should be required, while Participant-8 has stated that it would be more appropriate for administrators to work in an environment they like. Participant-5, who is among the participants who agreed that administrators should work in different institutions after a certain amount of time, has stated "They say that no authority and position is everlasting. 8 years is a sufficient period of time. The rotation of teachers is accurate from this perspective. Teachers or administrators should not be the regular fixtures of schools."

What are your views on the article "Those, who request to be reassigned in case their administrative duties are not extended, cannot be assigned to the educational institutions they have last worked in, limited to the same assignment period"?

While Participant-2 Participant-3, Participant-6, Participant-7 and Participant-8 have stated negative views, the rest of the participants have underlined that this article is appropriate. Participant-2 has stated "If the 
administrator is successful, then he/she should continue in the sane institution" and suggested that this article should be kept a bit more flexible to take successful administrators into consideration.

What are your views and suggestions on the removal of the method of determining the assignment of head vice principals and vice principals on the basis of written examinations and determining their assignment on the basis of an appointment letter written by the newly assigned principals to educational institutions which have been assigned principals, the suggestion of the provincial director of national education and the approval of the governor?

All of the participants have underlined that it would be more fruitful if the school principle formed his own team and work with the people he gets along with, however in terms of the removal of the written examination, all of the participants with the exception of Participant-1 have stated negative views. Participant-11 has stated the following to explain his point of view: "I do not find this appropriate, since oral examinations in our country are not objective."

What are your views on the removal of the written examination in the selection of people who are wished to be assigned as principals for the first time and again and taking the oral examination as the basis?

All of the participants with the exception of Participant-1 have stated that the written examination practice should continue. Participant-1 has stated that the oral examination is more appropriate and explained his point of view as follows: "The written examination is based on memorization, whereas oral examinations are based on the power of expression, representation and communication. The principal of an institution should value communication, rather than knowledge. Therefore, I find this extremely useful." Paticipant-7 has stated "In my opinion, the most appropriate practice is the written examination, then in-service training and another examination after in-service training."

If you have other suggestions you would like to add for the written examination to be more objective, please state your suggestions: The administrators have stated the following in terms of the written examination being more objective:

a. In the Evaluation Committee, there should be an educator from Education Faculties, who is an expert in the area of Education Management, a psychologist, a teacher who does not have a union membership and an inspector (Participant-3)

Questions, whose answers rely on accurate information should be asked (Participant-2)

b. $\quad$ Camera recording should be done (Participant -2, Participant -5)

If there are members in the commission indicated in the article you would like to add or remove, please state them: "Evaluation committee: Two provincial directors of national education and two unit heads employed in provincial and district national education directorates, under the chairmanship of a provincial director of national education or a vice provincial director of national education to be designated by him, who will be determined by the provincial director of national education.

While Participant -1, Participant -5 and Participant -10 have stated that the commission is sufficient, Participant-7 has stated "What is important is the essence of the practice. People may always be arguable." The other participants have expressed their suggestions as follows:

a. In the Evaluation Committee, there should be an educator from the Education Faculties, who is an expert in the area of Education Management, a teacher who is not a member of a union and an inspector (Participant-3)

b. $\quad$ There should be teachers who are knowledgeable about the legislation (Participant -4)

c. There should be 1 teacher, 1 principal, 1 vice principal, 1 attendant, 1 parent and 1 student. One person from each stakeholder should be determined through drawing lots.

What are your views on the union representatives not being in the examination evaluation committee? In terms of union representatives being in the committee, all of the participants have stated a common view and expressed that union members should not be in the committee. Participant- 3 has stated "Leave aside being in the commission, unions should not have any influence on the committee in any way. The 
administrators should not be selected from certain unions. The candidates' union information should definitely not be known by the committee." Only Participant-1 and Participant-10 have stated that they have found this article of the regulation appropriate. Participant-2 has stated "This article is funny. While the school score should be more important, what is decisive is the score given by people outside the school." Participant-7 has stated "All of the people who give scores to the form in question act emotionally or have a political approach. Therefore, I do not find it very healthy."

What are your views on the article "The duty term of principals who make an application for their duty term to be extended in other educational institutions are extended by taking their preferences into consideration and determined in accordance with score superiority by the suggestion of the provincial director of national education and the approval of the governor" ? Participant-2, Participant3, Participant-7, Participant-8 and Participant-9 have stated that this article of the regulation is not appropriate and Participant-3 has stated "A principal's being sent to B school with a score (vote) received from A school is firstly not appropriate. He may continue at a school which is satisfied with his work." Participant-4 has stated that the practice is appropriate on the condition that it is performed by competent people in a just manner.

In the article "In case the scores of the candidates who request their duty term to be extended are equal, the successively the candidate with successively the highest service score, service duration in administration and service duration in teaching is assigned. If there is still a tie, then the candidate to be assigned is determined by drawing lots", should the priority be the candidate's service duration and service score, or carrying out scientific studies (such as having completed post-graduate education, writing books, articles)?

While Participant -1, Participant -2, Participant -3, Participant -4, Participant -7 and Participant -11 have stated that in case the scores of the candidates are equal, then carrying out scientific studies should be the priority before service duration and service score, the other participants stated in terms of equal scores that ordering the candidates in line with their service duration and service scores are more accurate. Participant-5 has stated "Service duration in administration should be the first in the ordering of the candidates. Academic career and success do not show that the person will be a good administrator. However, the courses and seminar a candidate has attended in relation to administration can be taken into consideration."

In the oral examination for candidates to be assigned as principals for the first time and again are evaluated in terms of the following:

a) Legislation (Constitution of the Republic of Turkey, Civil Servants Law no: 657, National Education Basic Law no: 1739, Primary Education and Training Law no: 222, Public Finance Management and Control Law no: 5018, Private Schools Law no: 5580, Decree Law on the Ministry of National Education's Organization and Duties no: 652 and other relevant legislation),

b) Analytical thinking and analysis skill,

c) Representation skill and competence level,

d) Reasoning power and comprehension level,

e) Communication skills, self-esteem and persuasion ability,

f) General culture.

If there are other issues which you think should be added to the oral examination, please state them: While Participant-1, Participant-3, Participant-4 and Participant-10 have found these subjects in the oral examination sufficient, Participant-11has stated that academic success should be added to these subjects as well. Participant- 2 and Participant- 8 have stated that there should not be an oral examination at all. Participant-7 has found the subjects indicated in the related article sufficient, however has stated that it is not possible to evaluate these subjects with a 30 minute interview and that it would be much more appropriate to evaluate candidates in a 102 month seminar after the written examination in every aspect. Participant-5 has stated "I do not believe that legislation is necessary in the oral examination for the reassigning of principals. This may not be necessary in even the first assignment, because there is no need to know all this by heart. It is easier to reach the legislation. If it must be asked, then the legislation knowledge which is case method centered can be tested. While analyzing this, analytical thinking, representation skill, reasoning power etc. will emerge." 
What are your views on the article "The final assignment scores of candidates who are successful in the oral examination are determined by adding the half of the score they receive on the Form in Attachment-2 which contains the Education, Rewards, Penalties and Service heading and the half of the score they receive from the oral examination"?

Participant-1, Participant-4 and Participant-7 have found the scoring ratios indicated in this article appropriate. Since Participant-9 has considered that it would be appropriate to select the candidates from people who are graduates of departments such as Political Sciences, Economics or Business Administration, he has stated that the criteria should completely be changed. Participant-2, Participant3, Participant-5 and Participant-10 have stated that the criteria are reasonable, however the ratios should be rearranged.

What are your views on the assignment of candidates as principals who receive 80 and over in the oral examination with the suggestion of the provincial director national education and the approval of the governor, taking their preferences into consideration as well in accordance with their score superiority?

While Participant-1, Participant-4, Participant-7 and Participant-10 have stated that the practice is appropriate, Participant-3, Participant- 8 and Participant-11 shave stated that a written examination would be more appropriate in place of an oral examination.

What do you think about determining the candidate by drawing lots in cases where there is still a tie in the article "In case the scores of the candidates are equal, the candidate with successively the highest evaluation score, oral examination score, service duration in administration, service duration in teaching is assigned? In case where there is still a tie, the candidate to be assigned is determined by drawing lots."

Participant-2, Participant-6, Participant-7 and Participant-11 have stated that they find the idea of determining the administrators by drawing lots in case there is still a tie reasonable. Participant- 2 has stated "The possibility of a tie is quite low. Firstly, whether the candidates are carrying out scientific studies can be a criterion. If there is a tie in all subjects, then drawing lots is reasonable." Participant-1 has stated that the oral examination needs to be repeated in case there is still a tie. Participant- 4 has suggested that criteria which measures skills should be added to this criteria. Participant- 3 and Participant- 8 has stated that it would be more appropriate if only written examinations were valid instead of oral examinations. Participant-8 has stated "In order for a more democratic Turkey and to prevent favoritism, the most appropriate system is the written system. It should be possible to appoint administrative managers in accordance with the result of the written examinations. All actions, methods, etc., work and operations other than this will be in vain and will not be beneficial. People will lose their determination and the strength to work, even their love of work besides being enemies."

\section{Discussion}

According to the findings of the study, a majority of the participants are against the modification of the regulation on the appointment and dislocation of administrators as a regulation on the assignment of administrators with the idea that "Today's assignments are unfortunately being done politically." The participants' underlining that selection of administrators should be removed from politics has also been expressed in literature and it has been stated that the assignment of candidates of education management to education management and all of the processes to be carried out while they are on duty should be removed from arbitrary and personal appreciation and the interferences of political parties and that they should be subject to objective practices in line with the requirements of the qualifications in their service only (Tortop, 1994, p.47). A majority of the participants have found teaching experience necessary in relation to the article in the regulation "Having the qualification of being able to be appointed to the educational institution to be assigned to as a teacher." The participants who have found teaching experience necessary have argued that since school administration is different in comparison to other institutions, the school administrators' having teaching experience will be helpful in giving a direction to education and teaching. Participant- 9 has stated that it would be more helpful if a part of the administrators at schools have teaching experience and the other part are graduates of areas such as public administration and business administration. Participant-9's idea 
that two pools in the process of selecting administrators for school administration displays parallelisms with the model Cemaloğlu (2005) suggests which is about Selection of School Administrator Candidates.

All of the participants have found the article "Not having been relieved of administrative duty in the last four years due to legal or administrative investigation" for people to be appointed as administrators appropriate, however Participant-2 and Participant-3 have found it more appropriate that this duration should include the whole employment period, stating "A person who has been relieved of administrative duty due to legal or administrative investigation not only in the last four years should never be appointed as an administrator." In terms of the qualifications to be sought for in administrators to be assigned to educational institutions, one of the common views of the administrators is having at least a post-graduate degree in the area of education management. Parallel to the findings of the study, while Arıkan (2007), Günay (2004), Cemaloğlu (2005), Özmen and Kömürlü (2010) and Yeloğlu (2008) state that they support taking post-graduate studies in the area of management during the selection of administrators into consideration, in the studies of Graczyk (1991) and Ishida (1997), it has been concluded that post-graduate education in the area of management creates positive results on school management. This should be taken into consideration by the MNE and universities and firstly school principals, then their assistants should be given the change to do post-graduate studies. This view is successively followed by having at least three years of experience in administrative levels, being successful in the levels a person works as an administrator, receiving a valid score in the written examination which has validity and reliability prior to the oral examination, possessing top level leadership and communication skills and taking place in at least one scientific project.

According to the findings of the study, all participants with the exception of Participant- 6 and Participant-8 have stated that they regard giving priority of teachers who have vocational knowledge and wish to be administrators to middle schools which aspire to have an occupation within the scope of the regulation. The participants have underlined that vocational schools such as sports, industrial vocational. Trade vocational, fine arts and religious high-schools have unique terms of their own and that they agree about giving priority to teachers of these branches. In the study, in terms of the presence of union representatives in the provincial evaluation commission, all participants have agreed on a common point and have stated that union members should not be in the commission. In relation to this subject, Participant-3 has stated "Leave aside being in the commission, unions should not have any influence on the committee in any way. The administrators should not be selected from certain unions. The candidates' union information should definitely not be known by the committee."

In terms of the extension of duty term of administrators with the approval of the governor, all of the participants with the exception of Participant- 1 and participant-10 agreed that the governorship should not be a part of this process, on the grounds that governorships will be left under pressure and the administrators of governorships will not have sufficient chance to get to know administrators. As a recommendation, it can be emphasized that firstly the competencies for education administration need to be determined and in this respect, the required training prior to the service should be given and thus, comprehensive and continuous in-service seminars in which administrators can develop themselves during their services can be organized. In addition, completing post-graduate education in the education sciences departments of universities in the selection process of administrators can be a prerequisite and awards received in terms of successively service duration, success during service duration and performance can be sought for. In the selection of administrators, the standards of the criteria to be applied should be predetermined and subjective evaluations should be prevented. In order for the selection to be objective, reliable and to have certain standards, evaluations should be done by experts and a neutral commission.

\section{References}

Arıkan, G. (2007). Analysis of Policies and Applications at School Administrators' Attaintment Process in Ministry of National Education (Unpublished Thesis). Beykent University, İstanbul.

Bakioğlu, A. \& Özcan, K. (2001). The Carrier Developments of Primary School Principals. Educational Sciences: Theory and Practices, 1, 39-57. 
Balyer, A. \& Gündüz, Y. (2011). Training School Principals in Different Countries: A New Model Proposal for the Turkish Educational System. The Journal of Theoretical Education Science, 4(2), 182-197.

Cemaloğlu, N. (2005). The Training of School Principals and Their Employment inTurkey: Current Situation, Possible Developments in the Future and Problems. Gazi University Journal of Faculty of Education, 25(2), 249-274.

Charmaz, K. (2006). Constructing Grounded Theory: A Practical Guide through Qualitative Analysis. London: Sage Publications.

Coffey, A. \& Atkinson, P. (1996). Narratives and Stories. In Making Sense of Qualitative Data: Complementary Research Strategies, 54-82, Thousan Oaks, CA: Sage Publications.

Demir, S. B. \& Pınar, M. A. (2013). Investigation of Manager Opinions on the Content and Scoring Criteria of the 2011 Manager Appointment and Rotation RegulationTurkish Studies, 8(6), 123-143.

Dogan, S., Demir, S. B. \& Pinar, M. A. (2014). MONE 2013 Regulation for Administrator Assignment and Relocation Based on the Opinions of Administrators. Kuramsal Eğitimbilim Dergisi, 7(2), 224-245.

Graczyk, S. L. (1991). A Model for Planning Graduate Programs in School Business Administration. Planning and Changing, 22(2), 108-120.

Günay, E. (2004). Assessment of Ideas of Administrators and Teachers Related to Chosing, Traning and Appointing of Administrators for Educational Institutions: Sample of Ankara Province. (Unpublished Thesis). Ankara University, Ankara.

Ishida, H. (1997). MBA Education in Japan. The Experience of Management Education at the Graduate School of Business Administration, Keio University, Japan. Journal of Management Development, 16(3), 185196.

Korkmaz, M. (2005). Training of School Administrators: Problems-Conclusions and Suggestions. Gazi University Journal of Faculty of Education, 25(3), 237-252.

Marshall, C. \& Rossman, G. B. (1999). Designing Qualitative Research. London: Sage.

MONE (2014). Ministry of National Education. Regulation for Attainment and Rotation of Administrators at Educational Institutions. http://mevzuat.meb.gov.tr/html/egikuryon_1/egikuryon_1.html. (28/03/2015).

Miles, M. B. \& Huberman, A. M. (1994). Qualitative Data Analysis: An Expanded Sourcebook. London: Sage Publications.

Mills, G. E. (2003). Action Research a Guide for the Teacher Researcher. Boston: Pearson Education.

Özmen, F. \& Kömürlü, F. (2010). Ideas of Educators About Application of National Education Ministry on Selection and Appointing Administrators. Sosyal ve Beşeri Bilimler Dergisi, 2(1), 25-32.

Patton, Q. M. (2002). Qualitative Evaluation and Research Methods. London: Sage Publications.

Serin, S. (2007). Assessment of Primary School Administrators' Success by Classroom and Branch Teachers (Sample of Siirt Province). (Unpublished Thesis). Beykent University, İstanbul.

Silah, M. (2001). Personel Motivation for Improving the Quality of Work at Educational Organizations. C.U. Journal of Economics and Administrative Sciences, 2(1), 95-109.

Silverman, D. (2005). Doing Qualitative Research: A Practical Handbook. London: Sage Publicatations.

Süngü, H. (2012). Appointment and Training of School Administrators in Turkey, Germany and England. Sakarya University Journal of Education. 1(3), 33-48.

Taş, A. \& Önder, E. (2010). Comparison of Regulations Published in 2004 and After 2004 Related to Appointment and Rotation of Administrators at Educational Institutions. Süleyman Demirel University, Journal of Institute of Social Sciences, 2(12), 171-185.

Tortop, N. (1994). Personel Management. Ankara: Yargı Publishing.

Turan, S. \& Şişman, M. (2000). Standards for School Administrators: Thoughts on Knowledge Bases of Educational Administrators. Balıkesir University Journal of Institute of Social Sciences, 3(4), 68-87.

Yeloğlu, D. (2008). Assessment of School Administrators' Ideas Related to Choosing and Appointment of Educational Institutions' Administrators. (Unpublished thesis). Yeditepe University, İstanbul.

Yıldırım, A. \& Şimşek, H. (2005). Qualitative Research Methods in Social Sciences, (5th Ed.). Ankara: Seçkin Publishing. 